Proceedings

\title{
Comparison of the property of merocyanine-dye mixed L/LB film and Realistic mol. model
}

\section{メロシアニン色素混合 L・LB膜の実分子モデルと基礎物性}

\author{
Yusuke MIYAMOTO and Sadao UEGUSA \\ Department of Electrical Engineering, Tokai University, 1117 Kitakaname, Hiratsuka, Kanagawa, 259-12, Japan \\ TEL:81-0463-58-1211(EXT. 4162) \\ Kenichiro NAKAMURA \\ Department of Optical Engineering, Tokai University, 1117 Kitakaname, Hiratsuka, Kanagawa, 259-12, Japan \\ TEL :81-0463-58-1211 \\ Takanobu KUMAMOTO \\ Department of Chemistry, Tokai University, 1117 Kitakaname, Hiratsuka, Kanagawa, 259-12, Japan \\ TEL:81-0463-58-1211 \\ ( Received 14, November 1998 Accepted 12, June 1999)
}

Realistic molecular model was applied for characterizing the actual merocyanine-dye mixed L/LB film.

Keywords:merocyanine-dye mixed L/LB film, Realistic mol. model, property

\section{I . INTRODUCTION}

これまでに作成されたローダミンB色素混合LB膜の実分子 モテルは、それ以前に作製された棈円分子モテルのデータに 比べ、遥かに実際の実験結果に近い值を示すことが確認され ている'。このことから、メロシアニン色素混合LB膜において も、同様に好結果が得られるのではないかという予測のもと に、本研究に適用した。

また、メロシアニン色素混合LB膜の基礎物性に関して、こ れまで研究されたメロシアニン色素混合LB膜の物性の中で、 膜圧の変化による L B 膜の状態変化を調べた例はない。従っ て、膜圧の変化によって L B 膜の吸光度特性がどのように変 化するかを基本に、メロシアニン色素混合LB膜の基礎物性を 実分子モテルの結果と比較し、より詳細に検討した。

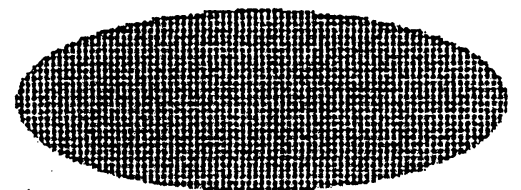

(a)Elliptical model

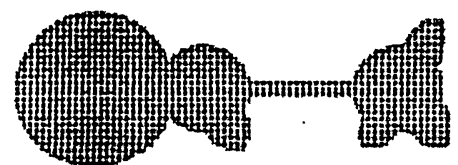

(b)Realistic mol. model

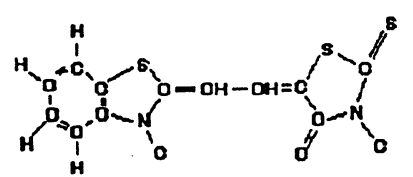

(c)molecular formula model

FIG.1. model of merocyanine-dye mixed L/LB film
II. EXPERIMENTAL メロシアニン色素混合LB膜の実分子モデルについて

メロシアニン色素及びアラキジン酸の分子の化学式を文献 で調查し、分子構造に従い原子を配列した時の分子外形の法 楽線を求めて、それを分子の近似モテルとした。そして、そ の面積を計算し求めた。また、ある一定区画内に、メロシア ニン色素とアラキジン酸のモテル分子をパソコン画面上に一 定比率で敷き詰め、両分子のモル比率を、アラキジン酸/メロ シアニン色素 $=\mathrm{Ma} / \mathrm{Mm}$ とし、 $\mathrm{Ma} / \mathrm{Mm}=0.5,1.0,1.5,2.0 .3 .0$ の 5 種類とした。

メロシアニン色素混合LB膜の基礎物性について

モル比1.0の場合メロシアニン色素6.0mg、アラキジン酸 3. $1 \mathrm{mg}$ をクロロホルム30mlと混ぜ合わせた。 LB装置のトラフ 上にマイクロシリンジにて混合溶液を $500 \mu$ l滴下し、装置を 作動させ L膜の $\pi$-A曲線を求めた。次に上記混合溶液をLB装

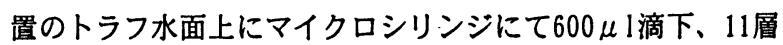
のLB膜を作製し、膜圧を $25,30,35,40,45 \mathrm{mN} / \mathrm{cm}^{3}$ と変化させた。 そして、完成したLB膜を吸光度測定器で、吸光度を測定し、 実験テータと実分子モテルの值を比較検討した。

\section{RESULT}

メロシアニン色素混合LB膜の実分子モテルについて

メロシアニン色素の分子量は602. 907、アラキジン酸の分子 量は、312.535であることや分子構造は文献により明らかであ $3^{2}$ 。この值をTable. 1 とした。また、LB膜の構造から親水基 のみを対象にモデル化し、このモテルを実分子モテルと呼ぶ こととした。 
TABLE.1. Nature of LB molecular ${ }^{2}$

\begin{tabular}{|c|c|c|}
\hline & \multicolumn{2}{|c|}{ Pigment } \\
\cline { 2 - 3 } & Merocyanine & Arachidic acid \\
\hline Molecular formula & $\mathrm{C}_{32} \mathrm{H}_{40} \mathrm{~N}_{2} \mathrm{O}_{3} \mathrm{~S}_{3}$ & $\mathrm{CH}_{3}\left(\mathrm{CH}_{2}\right)_{13} \mathrm{COOH}$ \\
\hline molecular weight & 602.907 & 312.5348 \\
\hline $\begin{array}{c}\text { Molecular formula } \\
\text { hydrophilic group }\end{array}$ & $\mathrm{C}_{13} \mathrm{H}_{4} \mathrm{~N}_{2} \mathrm{OS}_{3}$ & $\mathrm{C}_{2} \mathrm{O}_{2}$ \\
\hline $\begin{array}{c}\text { molecular weight of } \\
\text { hydrophilic group }\end{array}$ & 560.5106 & 56.0208 \\
\hline area $\left(\AA^{2}\right)$ & 57.12 & 5.72 \\
\hline
\end{tabular}

メロシアニン実分子モテルにおいて、実際のLB膜の分子配 列がどのような状態にあるのか判断が難しいため、一定区域 内に並べる方法として、Fig. 2 に示すように整列させたもの と乱雑に並べた 2 例を作製した。

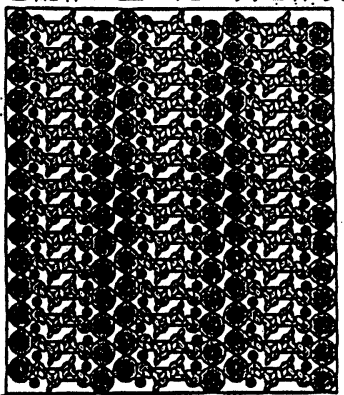

(a)Order

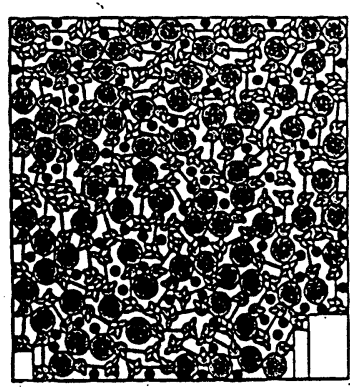

(b)Disorder
FIG.2. Realistic mol. model simulation

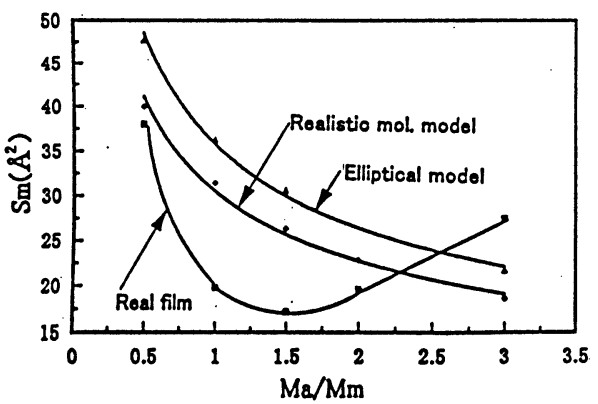

FIG.3. Connection of $\mathrm{Ma} / \mathrm{Mm}$ and $\mathrm{Sm}$

また、Fig. 3 に実際のLB膜と実分子モテルおよび棈円分子 モテルの関係を示した。この図からメロシアニン実分子モデ ルは、楕円分子モテルと比較すると、実験結果により近い值 を示すことを確認した。各々の実分子モテルのMa/Mmに対する 平均分子占有面積（以後、Smと称する）の特性は、Table 2, 3から両者はほほ一致しその間の有意差は認められない。ま た、 $\mathrm{Ma} / \mathrm{Mm}=1.0$ 場合、メロシアニン実分子モテルから、圧 縮率が高く各分子が最も密着した状態にあると考えられる。

TABLE. 2. Order model of Molecule occupation area

\begin{tabular}{|c|c|c|c|c|}
\hline $\mathrm{M} 2 / \mathrm{Ma}$ & Merocyanine & Arachidic acid & Division area $\left(A^{\prime}\right)$ & Kolecule occupatlon area $\left(A^{2}\right)$ \\
\hline 0.5 & 84 & 12 & 7802 & 40.0 \\
\hline 1 & 34 & 84 & 7843.5 & 31.4 \\
\hline 1.5 & 72 & 108 & 6971.25 & 26.3 \\
\hline 2 & 72 & 144 & 8099.75 & 22.8 \\
\hline 3 & 72 & 216 & 7944 & 18.6 \\
\hline
\end{tabular}

TABLE.3. Disorder model of Molecule occupation area

\begin{tabular}{|c|c|c|c|c|}
\hline $\mathrm{Ka}_{\mathrm{a}} / \mathrm{Kan}_{\mathrm{m}}$ & Merocyunine & Aruchidic acid & Divislon area $\left(A^{\prime}\right)$ & Holecule occupallon area $\left(A^{\prime}\right)$ \\
\hline 0.5 & 78 & 39 & 7360 & 10.0 \\
\hline 1 & 78 & 78 & 7360 & 31.1 \\
\hline 1.5 & 76 & 114 & 7425 & 28.3 \\
\hline 2 & 74 & 118 & 7569.25 & 22.8 \\
\hline 3 & 69 & 207 & 7569.25 & 18.6 \\
\hline
\end{tabular}

メロシアニン色素混合LB膜の基礎物性について

$\mathrm{Ma} / \mathrm{Mm}=1.0$ の場合の $\pi$-A曲線を測定した。また、膜圧= $25,30,35,40,45 \mathrm{mN} / \mathrm{cm}^{3}$ 時の吸光度の測定結果の各々をグラフ 化、Fig. 4 とし、実分子モテルと $\pi$-A測定結果との比較検討 も行った。 $\pi$-A曲線より、分子占有面積 $11.0 \AA^{2}$ 付近から、 23. $5 \AA^{2}$ 付近まで固体膜を形成しているものと推測される。さ らに、膜圧 $28 \mathrm{mN} / \mathrm{cm}^{2}$ 以下は液体膜及び気体膜に相当し、膜圧 $35 \mathrm{mN} / \mathrm{cm}^{2}$ 以上は膜が崩壊しているものと考えられる。 $\mathrm{Ma} / \mathrm{Mm}$ 対するSmは、実験の場合 $\mathrm{Ma} / \mathrm{Mm}=2.3 \sim 3.0$ において実分子モテ ルのS范上回る。この理由として、モテルを製作するときは 親水基のみを用いているが、実験では疎水基がぶつかり合い 本モテルのような密着した分子構造を取ることが困難なので はないかと推測される。また、Fig. 4より、吸光度では膜圧 $45 \mathrm{mN} / \mathrm{cm}^{2}$ 最大を示すが、膜圧 $40 \mathrm{mN} / \mathrm{cm}^{2} に て$ 吸光度が降下し ていることからも L B 分子の圧縮による変形が明らかである。 したがい、固体膜範囲内では膜圧 $35 \mathrm{mN} / \mathrm{cm}^{2}$ とき吸光度が最 も大きな值を示すことが明らかになった。

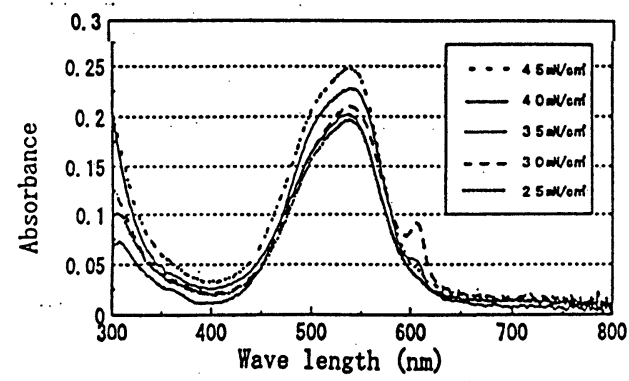

FIG.4. Connection of absorbance and pressure to film

\section{CONCLUSION}

本研究で作製した害分子モテルは、分子構造と実際のLB膜 の物性との因果関係を追及していく上で効果があった。実分 子モテルの平均分子占有面積は、分子の配列が整列していよ うと乱雑に並んでいようと、有意差はなかった。また、Smと $\mathrm{Ma} / \mathrm{Mm}$ の関係より、実分子モテルと実際のLB膜の特性の間に相 違が生じる可能性があることが明らかになった。その原因と しては、メロシアニン分子の側鎖などの分子結合部の加圧に よる変形を実分子モテルでは想定していなかったからである と思われる。さらに、固体膜範囲内では膜圧 $35 \mathrm{mN} / \mathrm{cm}^{2}$ のき 吸光度が最も大きな值を示すことが明らかになった。

\section{REFERENCES}

${ }^{1} \mathrm{~K}$. Nakamura, Y. Nakajima, Characteristic of Dye mixed L/LB film and trial production, Graduation thes is, Department of Electrical Engineering,Tokai University, (1997)

${ }^{2} \mathrm{~K}$. Iriyama. An organic super-pale film. (1992) Presented at ' 98 SAS Intelligent Symposium 